\title{
AKSES NELAYAN TERHADAP SUMBER DAYA PESISIR DI KAWASAN PERTAMBANGAN
}

\author{
Fishery Acess to Coastal Resources in Mining Area \\ Yossika Tantri Wandan Sari ${ }^{*}$ dan Arif Satria \\ Departemen Sains Komunikasi dan Pengembangan Masyarakat, Fakultas Ekologi Manusia, IPB \\ *)Email : yossikatwsari@yahoo.co.id
}

Diterima 12 Oktober 2011 / Disetujui 23 November 2011

\begin{abstract}
The establishment of the area, which is established by determining boundaries that can be used to organize natural resources owenership, is a way to avoid natural resources conflict. The purposes of this study are: 1) to analyze the participation of fishers in determining coastal zones at Kelurahan Cilacap; 2) to analyze the impact of coastal zoning on fishers natural resoruces access in Cilacap Village; and 3) to analyze the relationship between change of fisher's natural resources access and resource conflict in Cilacap Village. The results of this study conclude that: 1) there is lack of fishers participation in determining coastal zoning; 2) there are some impacts of zoning which influence fishers' natural resources access; and 3) the factor that causing conflicts in Cilacap Village was coastal pollution from tanker ship accidents. The conflicts in Cilacap Village, which are caused by coastal pollution from tanker ship accidents, give both negative and positive impacts for fishers. Some of the negative impacts are decreasing trust, escalating moral problems, and decreasing productivity. On the other hand, the positive impacts are reinforcement bonds within fishers group, fishers are capable to adapt within the environment, and improvement of fisheres' knowledge improved.
\end{abstract}

Keywords: coastal zoning, resource access, conflict.

\section{ABSTRAK}

Pembentukan daerah, yang didirikan dengan menentukan batas-batas yang dapat digunakan untuk mengatur kepemilikan sumber daya alam, adalah cara untuk menghindari konflik sumber daya alam. Tujuan dari penelitian ini adalah: 1) untuk menganalisis partisipasi nelayan dalam menentukan wilayah pesisir di Kelurahan Cilacap; 2) untuk menganalisis dampak zonasi pesisir pada akses sumber daya alami alam nelayan di Desa Cilacap; dan 3) untuk menganalisis hubungan antara perubahan akses sumber daya alam nelayan dan konflik sumber daya di Desa Cilacap. Hasil penelitian ini menyimpulkan bahwa: 1) kurangnya partisipasi nelayan dalam menentukan zonasi pesisir; 2) ada beberapa dampak dari zonasi yang mempengaruhi akses sumber daya alam nelayan; dan 3) faktor yang menyebabkan konflik di Desa Cilacap adalah pesisir polusi dari kecelakaan kapal tanker. Konflik di Desa Cilacap, yang disebabkan oleh pencemaran pesisir dari kecelakaan kapal tanker, memberikan baik dampak negatif dan positif bagi nelayan. Beberapa dampak negatif penurunan kepercayaan, masalah moral yang meningkat, dan penurunan produktivitas. Di sisi lain, dampak positif penguatan obligasi dalam kelompok nelayan, nelayan mampu beradaptasi dalam lingkungan, dan peningkatan pengetahuan nelayan lebih baik.

Kata kunci: zonasi pesisir, akses sumber daya, konflik.

\section{PENDAHULUAN}

\section{Latar Belakang}

Indonesia merupakan negara kepulauan terbesar di dunia. Berdasarkan data, Indonesia memiliki pulau sebanyak 17.504 pulau dengan panjang pantai $95.181 \mathrm{~km}$. Luas laut yang dimiliki Indonesia sekitar 5,8 juta $\mathrm{km}^{2}$ dengan pembagian 0,8 juta $\mathrm{km}^{2}$ perairan teritorial, 2,3 juta $\mathrm{km}^{2}$ perairan nusantara, dan $2,7 \mathrm{~km}^{2}$ perairan $\mathrm{ZEE}^{1}$. Kekayaan alam yang terkandung di dalamnya adalah 350 fauna, 28.000 flora, 110.000 mikroba, 600 terumbu karang, dan 40 genera (termasuk di dalamnya ikan, udang, moluska, kerang mutiara, rumput laut, kepiting, mangrove, hewan karang, dan biota laut lainnya) ${ }^{2}$. Selain makhluk hidup, di

\footnotetext{
${ }^{1}$ Kelautan dan Perikanan dalam Angka, 2009

2 Betapa luas laut Indonesia « RichOcean INDONESIA Blog.htm
} 
pesisir dan dalam laut juga terkandung sumber daya alam yang tidak dapat diperbaharui, seperti minyak bumi, pasir, timah, dan lain sebagainya. Selain itu kualitas sumber daya alam yang tidak dapat diperbaharui tersebut memiliki kualitas tinggi sehingga banyak diantaranya yang diekspor.

Kekayaan alam yang melimpah ini membutuhkan suatu pengelolaan yang baik agar tidak ada konflik mengenainya. Hal ini menyebabkan pemerintah membuat berbagai macam undang-undang yang dapat mengatur sumber daya alam tersebut. Tahun 1999 telah diresmikan dan dilaksanakan Undang-Undang Otonomi Daerah yang kemudian diamandemen menjadi UU RI Nomor 32 Tahun 2004. Landasan pelaksanaannya didasarkan pada PP Nomor 129 Tahun 2000. Dalam undang-undang tersebut dijelaskan mengenai pemekaran daerah, yaitu suatu proses membagi satu daerah administratif yang sudah ada menjadi dua atau lebih daerah otonomi baru ${ }^{3}$. Dalam UU No. 32 Tahun 2004 Pasal 18 telah diatur batas kewenangan pemerintah pusat, provinsi, dan kabupaten/kota terhadap perairan laut, namun dalam pelaksanaannya masih terjadi tumpang tindih kewenangan.

Tiga tahun kemudian, pemerintah mengeluarkan undangundang yang berhubungan dengan wilayah pesisir dan pulau-pulau kecil. Dalam Undang-Undang No. 27 Tahun 2007 tersebut dijelaskan mengenai sistem zonasi. Sistem itu berhubungan dengan pemanfaatan dan pengelolaan sumber daya alam pesisir di suatu wilayah. Hak zonasi tersebut merupakan bagian dari rencana pembangunan jangka panjang setiap daerah. Di dalam undang-undang tersebut diatur pula mengenai Hak Pengusahaan Perairan Pesisir serta alokasi pemanfaatan sumber daya pesisir.

Selain Undang-Undang No. 27 Tahun 2007, terdapat pula undang-undang yang berkaitan dengan pengelolaan wilayah, yaitu Undang-Undang No. 26 Tahun 2007. Dalam undang- undang ini dijelaskan mengenai tata kelola ruang baik di tingkat nasional, provinsi, maupun kabupaten dan kota. Selain itu pengelolaan tata ruang ini juga mencangkup wilayah perkotaan dan perdesaan ${ }^{4}$. Ketiga undang-undang tersebut merupakan pedoman bagi pemerintah pusat, pemerintah provinsi, dan pemerintah daerah untuk menata wilayah mereka yang berkaitan dengan sumber daya alam. Hal ini penting untuk meminimalisir terjadinya konflik atas sumber daya alam di berbagai daerah, termasuk di Kabupaten Cilacap, Jawa Tengah.

Kabupaten Cilacap merupakan daerah terluas di Jawa Tengah. Wilayah ini berbatasan dengan Samudera Indonesia di sebelah selatan, Kabupaten Banyumas, Kabupaten Brebes, dan Kabupaten Kuningan di sebelah utara, Kabupaten Kebumen di sebelah timur, dan Kabupaten Ciamis serta Kota Banjar di sebelah barat.

\footnotetext{
3 Djoko Harmantyo, 2007

${ }^{4}$ Undang-Undang No 26 Tahun 2007
}

Salah satu mata pencaharian masyarakat Cilacap adalah nelayan dengan luas sebaran penangkapan $5.200 \mathrm{~km}^{2}$. Selain itu, Cilacap juga memiliki kekayaan sumber daya mineral yang melimpah, seperti minyak bumi dan gas bumi, batu bara, emas, pasir besi, dan gamping ${ }^{5}$. Hal ini menyebabkan Cilacap merupakan daerah yang strategis untuk investasi para perusahaan. Terdapat tujuh perusahaan pertambangan atau perusahaan yang terkait dengan arang tambang di Kabupaten Cilacap. Perusahaan-perusahaan tersebut ada yang berfungsi sebagai pengolahan BBM, penyaluran minyak, PLTU, penambangan batu untuk bahan semen, dan distributor aspal $^{6}$

Selain itu di kawasan perairan Cilacap yang berbatasan langsung dengan Samudera Indonesia ini terdapat sebuah pelabuhan internasional bernama Pelabuhan Tanjung Intan. Berdasarkan wawancara awal yang dilakukan dengan pihak Dinas Administrasi Pelabuhan diketahui bahwa jalur pelayaran ini dilalui oleh kapal-kapal nonnelayan, seperti kapal tanker, kapal tongkang, dan kapal kargo yang membawa bermacam-macam muatan. Beberapa jenis muatan tersebut adalah batu bara yang digunakan sebagai bahan bakar PLTU, gamping yang berasal dari Pulau Nusakambangan, serta minyak bumi. Keberadaan kapal-kapal tersebut sering kali meresahkan nelayan. Bahkan keadaan ini juga memicu konflik antara nelayan dengan pihak pemilik kapal tanker tersebut karena nelayan merasa dirugikan. Konflik antara kedua sektor tersebut dapat menyebabkan dampak berupa hancurnya harta benda dan jatuhnya korban manusia (Soekanto, 2002). Selain itu masyarakat nelayan dapat melakukan aksi anarki sebagai akibat dari pelayaran yang dilakukan oleh kapal tanker.

Menurut Harmantyo (2007), Indonesia memiliki potensi konflik kewilayahan yang tinggi dan meningkat setelah adanya peraturan otonomi daerah. Meskipun demikian untuk konflik horizontal di wilayah pesisir belum tentu ada hubungannya dengan otonomi daerah karena sudah berlangsung sejak dulu (Satria et al., 2002 dalam Hikmah, 2008).

\section{Perumusan Masalah}

Berdasarkan latar belakang yang telah disampaikan di atas dapat diketahui bahwa dalam wilayah pesisir terdapat berbagai macam pihak pengelola, yaitu pemerintah, masyarakat, dan perusahaan (baik perusahaan swasta maupun negara). Keadaan seperti ini juga terjadi di wilayah Kabupaten Cilacap khususnya Kelurahan Cilacap di mana dalam suatu lokasi terdapat tiga pihak berkepentingan yang berhubungan dengan sumber daya pesisir.

Permasalahan yang dalam kasus ini terjadi bukan hanya merupakan ketersediaan atau keberadaan sumber daya

\footnotetext{
${ }^{5}$ www.cilacapkab.go.id

${ }^{6}$ Undang-Undang No 27 Tahun 2007
} 
alam pesisir itu sendiri melainkan proses pengelolaan dan hubungan berbagai pihak yang terkait di dalamnya. Hal ini berkaitan pula dengan zonasi-zonasi yang diciptakan di wilayah pesisir tersebut untuk para pihak yang melakukan aktivitas di sana. Pembagian willayah berupa zonasi ini dapat menyebabkan suatu konflik jika ada pihak-pihak tertentu merasa dirugikan. Konflik yang terjadi dapat menyebabkan suatu dampak yang merugikan berbagai pihak jika hal tersebut tidak diatasi dengan tepat. Konflik ini pula dapat menggambarkan bagaimana sistem zonasi itu terjadi pada awalnya.

Terkait berbagai hal tersebut maka dirumuskan pertanyaan penelitian seperti di bawah ini, yaitu 1) bagaimana tingkat partisipasi nelayan berperan dalam menentukan zonasi wilayah pesisir? 2) bagaimana pengaruh zonasi wilayah pesisir terhadap akses sumber daya alam nelayan? dan 3) bagaimana pengaruh perubahan akses sumber daya alam nelayan terhadap konflik yang terjadi?

\section{Tujuan Penelitian}

Berdasarkan latar belakang dan rumusan masalah yang telah disampaikan sebelumnya maka tujuan dari penelitian ini adalah 1) menganalisis keterkaitan tingkat partisipasi nelayan dalam menentukan zonasi wilayah pesisir; 2) menganalisis pengaruh zonasi wilayah pesisir terhadap akses sumber daya alam nelayan; 3) menganalisis perubahan akses sumber daya alam nelayan terhadap konflik yang terjadi.

\section{Kegunaan Penelitian}

Penelitian ini memiliki kegunaan sebagai berikut:

1. bagi akademisi, untuk sumbangsih pemikiran dan sebagai landasan bagi penelitian ataupun kegiatan akademis lain yang berkaitan dengan penelitian ini;

2. bagi pemerintah, sebagai evaluasi dalam pengelolaan sumber daya pesisir yang melibatkan dua sektor, yaitu sektor perikanan dan pertambangan. Jika nantinya diketahui bahwa terdapat konflik antara kedua sektor maka dalam pengelolaan sumber daya pesisir tersebut perlu diperhatikan mengenai ke-pentingan kedua belah pihak. Hal ini bertujuan agar tidak ada lagi konflik yang terjadi antara kedua sektor tersebut di kemudian hari dan dapat saling meng-hargai akan keberadaan masing-masing aktor;

3. bagi swasta, sebagai acuan dan evaluasi dalam menentukan kebijakan dan pengolahan tambang; dan

4. bagi masyarakat umum, sebagai tambahan pengetahuan dan wawasan mengenai hubungan antara dua sektor, yaitu sektor perikanan dan pertambangan di pesisir. Sedangkan bagi masyarakat pesisir, penelitian ini diharapkan dapat memperlihatkan bagaimana pengaruh keberadaan perusahaan pertambangan yang terkait dengan pengelolaan sumber daya alam di wilayah pesisir.

\section{PENDEKATAN TEORITIS}

\section{Tinjauan Pustaka}

\section{Pesisir}

Wilayah pesisir adalah suatu wilayah peralihan antara daratan dan lautan. Apabila ditinjau dari garis pantai, maka suatu wilayah pesisir memiliki dua macam batas, yaitu batas yang sejajar garis pantai dan batas yang tegak lurus terhadap garis pantai. Sumber daya pesisir dan pulau-pulau kecil adalah sumber daya hayati, sumber daya nonhayati, sumber daya buatan, dan jasa-jasa lingkungan ${ }^{7}$. Ekosistem pesisir dapat bersifat alami ataupun buatan. Potensi pembangunan yang terdapat di wilayah pesisir dan lautan secara garis besar terdiri dari tiga kelompok, yaitu sumber daya dapat pulih, sumber daya tak dapat pulih, dan jasa-jasa lingkungan.

Menurut Dahuri dkk. (1996) perencanaan dan pengelolaan wilayah pesisir secara sektoral dapat menimbulkan konflik kepentingan antarsektor yang berkepentingan yang melakukan aktivitas pembangunan pada wilayah pesisir dan lautan yang sama. Oleh karena itu, dibutuhkan suatu pengelolaan wilayah pesisir secara terpadu adalah suatu pendekatan pengelolaan wilayah pesisir yang melibatkan dua atau lebih ekosistem, sumber daya, dan kegiatan pemanfaatan secara terpadu guna mencapai pembangunan wilayah peisir secara berkelanjutan. Dalam hal ini keterpaduan mengandung tiga dimensi, yaitu sektoral, bidang ilmu, dan keterkaitan ekologis.

\section{Partisipasi}

Aprinova (2006) mengutip Sjaifudian (2002) menyatakan bahwa partisipasi adalah proses ketika warga komunitas, baik sebagai individu maupun kelompok sosial, organisasi atau lembaga, mengambil peran dalam proses perencanaan, pelaksanaan dan pemantauan kebijakan-kebijakan yang langsung mempengaruhi kehidupan mereka. Cohen dan Uphoff (1979) membedakan partisipasi berdasarkan tahapannya, yaitu 1) partisipasi dalam pembuatan keputusan, kebijaksanaan, perencanaan pembangunan; 2) partisipasi dalam pelaksanaan program pembangunan; 3) partisipasi dalam memanfaatkan atau menggunakan hasil pembangunan, dan 4) partisipasi dalam mengevaluasi dan mengawasi pembangunan.

\section{Faktor yang Mempengaruhi Partisipasi Nelayan}

Untuk mengetahui tingkat partisipasi masyarakat ada faktor-faktor yang berpengaruh terhadapnya. Beberapa faktor tersebut adalah tingkat pendidikan, umur, dan kesesuaian kegiatan dengan kebutuhan yang merupakan faktor pribadi (Madrie, 1986 dalam Farid, 2005). Menurut Soeryani, dkk. (1987) dalam Farid (2005), dikatakan bahwa tingkat partisipasi dipengaruhi oleh tingkat pendidikan dan kemiskinan. Syarat yang diperlukan agar masyarakat lebih berperan aktif dalam

\footnotetext{
${ }^{7}$ Undang-Undang No 27 Tahun 2007
} 
pembangunan adalah kemauan, kemampuan, dan kesempatan bagi masyrakat untuk berpartisipasi dalam proses pembangunan (Farid, 2005 mengacu pada Slamet, 1985). Hal ini dipengaruhi oleh umur, pendidikan, keterampilan, penghasilan, kelembagaan, kepemimpinan, budaya lokal, serta pengaturan dan pelayanan pemerintah.

\section{Kepemilikan Sumber Daya Alam}

Teori kepemilikan sumber daya alam yang digunakan adalah teori dari Ostrom dan Schlager dalam Satria (2009), terdapat empat tipe hak dalam pengelolaan sumber daya alam, yaitu 1) hak akses (access right) adalah hak untuk memasuki wilayah sumber daya yang memiliki batas-batas yang jelas dan untuk menikmati manfaat nonekstraktif; 2) hak pemanfaatan (withdrawal right) adalah hak untuk memanfaatkan sumber daya; 3) hak pengelolaan (management right) adalah hak untuk urut serta dalam pengelolaan sumber daya; 4) hak eksklusi (exclusion right) adalah hak untuk menentukan siapa yang boleh memiliki hak akses dan bagaimana hak tersebut dialihkan ke pihak lain, dan 5) hak pengalihan (alienation right) adalah hak untuk menjual atau menyewakan sebagian atau seluruh hak kolektif tersebut di atas.

Selain terdapat hak kepemilikan sumber daya alam dan aktor yang dapat memiliki hak-hak tersebut juga terdapat rezim-rezim kepemilikan sumber daya alam (Satria 2009), yaitu 1) rezim negara (state property), yaitu sumber daya alam dimiliki oleh seluruh warga negara dan pengalihan pengelolaan dilakukan oleh pemerintah; 2) rezim swasta (private property), yaitu individu atau perusahaan memiliki hak atas sumber daya; 3) rezim masyarakat atau komunal (communal property), yaitu sumber daya dimiliki dan dikontrol oleh sekelompok masyarakat; dan 4) akses terbuka (open access), yaitu sumber daya dapat dimiliki oleh semua orang.

\section{Konflik}

\section{Definisi Konflik}

Teori terakhir yang digunakan adalah mengenai konflik. Konflik atau pertentangan adalah suatu proses sosial di mana individu atau kelompok berusaha memenuhi tujuannya dengan jalan menantang pihak lawan dengan ancaman atau kekerasan (Soekanto, 2002). Sementara itu, Daniel Webster dalam Pickering mendefinisikan konflik sebagai 1) persaingan atau pertentangan antara pihak-pihak yang tidak cocok satu sama lain; 2) keadaan atau prilaku yang bertentangan (misalnya pertentangan pendapat, kepentingan, atau antar individu); 3) perselisihan akibat kebutuhan, dorongan ,keinginan, atau tuntutan yang bertentangan; dan 4) perseteruan.

\section{Jenis Konflik}

Konflik memiliki dua macam bentuk, yaitu konflik vertikal dan horizontal. Konflik vertikal melibatkan dua atau lebih kelompok yang memiliki stratifikasi sosial yang berbeda, seperti kaum elit dengan masyarakat biasa sedangkan konflik horizintal adalah konflik yang terjadi antara dua kelompok atau lebih yang memiliki stratifikasi sosial yang sama, seperti antar masyarakat atau antar pemerintah (Maskanah et al., 2000 dalam Susan, 2010). Konflik juga memiliki sifat yang berbeda. Seperti dalam Susan (2010) yang mengacu pada Fisher (2001), sifat konflik dibagi menjadi empat, yaitu:

1. konflik tanpa konflik adalah konflik yang memiliki situasi stabil. Dalam hal ini bukan berarti tidak terjadi konflik, melainkan terdapat situasi-situasi yang menjadikan keadaan menjadi stabil, yaitu masyarakat mampu menciptakan struktur sosial yanng bersifat mencegah ke arah konflik kekerasan serta sifat budaya yang memungkinkan anggota masyarakat menjauhi permusuhan dan kekerasan;

2. konflik laten adalah suatu keadaan yang di dalamnya terdapat banyak permasalahan, sifatnya tersembunyi, dan perlu diangkat ke permukaan agar bisa ditangani;

3. konflik terbuka adalah situasi ketika konflik sosial telah muncul ke permukaan yang berakar dalam dan sangat nyata serta memerlukan berbagai tindakan untuk mengatasi akar penyebab dan berbagai efeknya;

4. konflik di permukaan, yaitu konflik yang memiliki akar dangkal atau tidak berakar dan terjadi hanya karena kesalahpahaman mengenai sasaran yang dapat diatasi dengan meningkatkan komunikasi.

Sementara itu Satria (2009) mengacu pada Satria (2006), terdapat tujuh macam konflik nelayan, yaitu:

1. konflik kelas, yaitu konflik yang terjadi akibat perbedaan kelas sosial nelayan dalam memperebutkan wilayah penangkapan. Akibatnya ada satu pihak yang memiliki wewenang lebih tinggi, sementara itu ada pihak lainnya yang didominasi (Adhuri, 2005);

2. konflik kepemilikan sumber daya, merupakan konflik yang terjadi dalam isu "ikan milik siapa" atau "laut milik siapa";

3. konflik pengelolaan sumber daya, merupakan konflik yang disebabkan oleh pelanggaran aturan pengelolaan baik yang terjadi antar nelayan maupun antara nelayan dengan pemerintah;

4. konflik cara produksi atau alat tangkap, merupakan konflik yang terjadi karena perbedaan alat tangkap;

5. konflik lingkungan, merupakan konflik yang terjadi akibat kerusakan lingkungan yang disebabkan oleh praktik salah satu pihak yang merugikan nelayan;

6. konflik usaha, merupakan konflik yang terjadi di darat akibat mekanisme harga ataupun sistem bagi hasil yang merugikan sekelompok nelayan;

7. konflik primordinal, merupakan konflik yang terjadi akibat perbedaan identitas, secara etnik, asal daerah, dan seterusnya. Akan tetapi konflik primordinal tidak pernah berdiri sendiri atau menjadi penyebab utama dalam suatu konflik. Konflik ini mengakibatkan terganggunya akses suatu pihak terhadap sumber daya (Adhuri, 2005) 


\section{Dinamika Konflik}

Fisher (2001) dalam Susan (2010), maka terdapat empat tahapan dinamika konflik, yaitu 1) prakonflik adalah periode pada saat terdapat suatu ketidaksesuaian sasaran di antara dua pihak atau lebih sehingga menimbulkan konflik; 2) konfrontasi, dalam tahap ini memperlihatkan pada saat konflik mulai terbuka; 3) krisis adalah puncak konflik. Dalam tahap ini terjadi aksi kekerasan; dan 4) pascakonflik adalah situasi diselesaikan dengan cara mengakhiri berbagi konfrontasi kekerasan, ketegangan berkurang, dan hubungan mengarah ke lebih normal di antara kedua belah pihak.

\section{Managemen Konflik}

Konflik yang terjadi dapat diselesaikan dengan berbagai macam cara. Menurut Soekanto (2002) terdapat beberapa bentuk akomodasi sebagai suatu proses, yaitu:

1. paksaan (coercion), suatu bentuk akomodasi yang prosesnya dilaksanakan oleh karena adanya paksaan. Dalam proses ini terdapat pihak yang lebih lemah dari lainnya. Pelaksanaannya dapat dilakukan dengan cara fisik ataupun psikologis;

2. kompromi (compromise), pihak yang terlibat saling saling mengurangi tuntutannya agar tercapai suatu penyelesaian terhadap perselisihan yang ada;

3. arbitrasi (arbitration), suatu cara untuk mencapai kompromi apabila pihak yang berhadapan tidak sanggup mencapainya sendiri. Pertentangan diselesaikan oleh pihak ketiga yang dipilih oleh kedua belah pihak atau badan yang memiliki kedudukan lebih tinggi dari pihak yang bertikai;

4. mediasi (mediation), dalam proses ini diundang pihak ketiga yang netral dalam soal perselisihan yang ada. Pihak ketiga bertindak sebagi penasihat dan tidak mempunyai wewenang untuk memberi keputusan;

5. konsiliasi (conciliation), suatu usaha untuk mempertemukan keinginan dari pihak yang berselisih demi tercapainya suatu tujuan bersama;

6. tenggang rasa atau toleransi (toleration), suatu bentuk akomodasi tanpa persetujuan yang formal,

7. berhenti (stalemate), kondisi di mana pihak yang bertentangan karena mempunyai kekuatan yang seimbang berhenti pada suatu titik tertentu dalam melakukan pertentangannya; dan

8. adjudikasi atau membawa masalah ke pengadialan (adjudication), penyelesaian pekara di pengadilan.

\section{Dampak Konflik}

Suatu konflik menghasilkan dampak bagi para pelaku yang terlibat di dalamnya. Konflik memiliki dampak positif dan negatif. Menurut Pickering (2001), manfaat dari konflik adalah motivasi meningkat, identifikasi masalah atau pemecahan masalah meningkat, ikatan kelompok lebih erat, penyesuian diri pada kenyataan, pengetahuan atau keterampulan meningkat, kreativitas mengingkat, membantu upaya mencapai tujuan, mendorong pertumbuhan. Sementara itu dampak negatifnya adalah produktivitas menurun, kepercayaan menurun, pembentukan kubu-kubu, informasi dirahasiakan dan arus komunikasi berkurang, timbul masalah moral, waktu terbuang sia-sia, proses pengambilan keputusan tertunda.

\section{Kerangka Pemikiran}

Sistem pemanfaatan sumber daya alam dapat berupa kebijakan mengenai hak pengelolaan sumber daya tersebut. Kebijakan pengelolaan wilayah pesisir dapat dipengaruhi oleh akses politik nelayan yang dilihat dari partisipasi nelayan terhadap pembentukan kebijakan tersebut. Akses politik ini dapat dipengaruhi oleh karakteristik nelayan yang dilihat dari usia, tingkat pendidikan, tingkat pendapatan, dan jumlah tanggungan.

Kebijakan pengelolaan wilayah pesisir dapat mempengaruhi perubahan akses nelayan terhadap sumber daya alam. Akses ini dilihat dari cangkupan wilayah dan hak pemanfaatan pesisir. Akses nelayan terhadap sumber daya alam ini juga dapat dipengaruhi oleh skala usaha nelayan yang dilihat dari skala kapal tangkap nelayan. Perubahan akses nelayan terhadap sumber daya alam dapat menyebabkan konflik berupa konflik kelas, konflik kepemilikan sumber daya, konflik pengelolaan sumber daya, dan konflik lingkungan. Konflik ini dapat diatasi atau diminimalisir dengan berbagai macam cara. Fokus penelitian ini adalah analisis konflik yang terjadi di Cilacap di mana hal ini dipengaruhi oleh akses politik nelayan berupa partisipasi dalam hal zonasi wilayah pesisir. Penelitian ini mengambil individu sebagai unit analisisnya dengan populasi berupa nelayan. Kerangka pemikiran dari penelitian ini dapat dilihat pada Gambar 1.

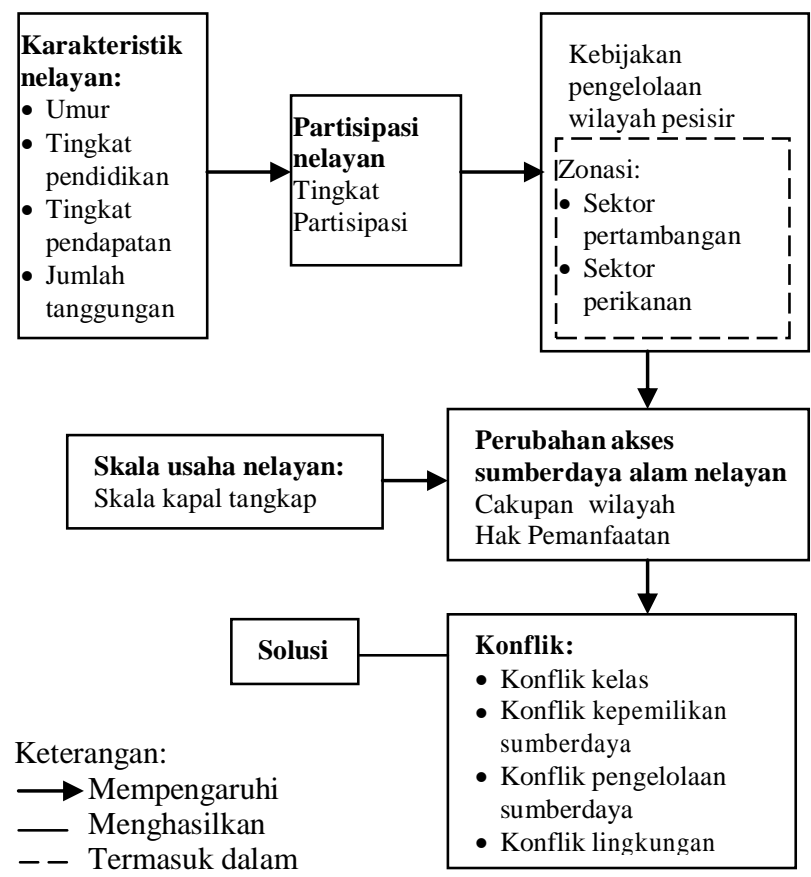

Gambar 1. Kerangka Pemikiran 


\section{Hipotesis Penlitian}

Hipotesis penelitian ini adalah diduga terdapat hubungan antara karakteristik nelayan terhadap akses politik nelayan.

\section{PENDEKATAN LAPANGAN}

\section{Lokasi dan Waktu Penelitian}

Penelitian ini menggunakan pendekatan kuantitatif didukung oleh analisis kualitatif. Pendekatan kuantitatif menggunakan metode survei dengan instrumen kuesioner untuk mengumpulkan data penelitian dari sejumlah sampel dalam populasi. Penelitian dilaksanakan di Kelurahan Cilacap, Kecamatan Cilacap Selatan, Kabupaten Cilacap. Lokasi tersebut dipilih secara sengaja (purposive) dengan alasan terdapat aktivitas pelayaran kapal tanker dan tongkang yang mengangkut sumber daya mineral berupa minyak bumi dan batu bara, terdapat masyarakat yang bermatapencaharian sebagai nelayan tangkap, dan terjadi konflik di wilayah tersebut. Penelitian dilakukan selama enam bulan yaitu dari bulan April hingga September 2011.

\section{Teknik Pengumpulan Data}

Mayoritas masyarakat di wilayah penelitian memiliki mata pencaharian sebagai nelayan. Dalam penelitian ini difokuskan kepada nelayan tradisional yang berstatus sebagai nahkoda dengan jarak tangkap pada jalur satu, yaitu sejauh enam mil. Maka populasi untuk penelitian ini adalah nelayan yang berstatus sebagai nahkoda dengan jarak tempuh pada jalur satu. Namun karena kelurahan ini memiliki RW dan jumlah nelayan yang juga sangat banyak maka peneliti melakukan penyempitan wilayah penelitian. Kelurahan ini tidak memiliki dusun sehingga secara adminsitrasi wilayah yang lebih kecil dalam kelurahan ini adalah Rukun Warga (RW). Maka peneliti memilih satu dari $18 \mathrm{RW}$ secara sengaja berdasarkan informasi dari informan yang terpercaya setelah melakukan wawancara dan diskusi sebagai wilayah penelitian. Pemilihan ini didasarkan pada aspek jumlah nelayan tradisional berstatus nahkoda terbanyak sehingga dipilih RW X dengan jumlah nahkoda sebanyak 74 orang. Maka populasi penelitian ini adalah nelayan yang berstatus sebagai nahkoda serta berdomisili di RW X. Rukun Warga (RW) X ini memiliki delapan RT di mana terdapat 9 nelayan di RT 01, 10 nelayan di RT 02, 8 nelayan di RT 03, 10 nelayan di RT 04, 13 nelayan di RT 05, 5 nelayan di RT 06, 10 nelayan di RT 07, dan 9 nelayan di RT 08. Selanjutnya dari semua RT tersebut diambil secara acak nelayan yang dijadikan responden penelitian.

Penelitian ini menggunakan wawancara mendalam dengan tokoh masyarakat setempat dan aparat pemerintah untuk mengetahui proses terjadinya konflik. Sedangkan untuk mengetahui karakteristik nelayan, akses politik, skala usaha nelayan, dan akses sumber daya alam nelayan dilakukan melalui survei dengan menggunakan kuesioner melalui wawancara. Untuk mendapatkan responden yang akan diwawancarai sesuai dengan kuesioner maka peneliti membuat seluruh daftar nama nelayan terlebih dahulu. Setelah itu ditentukan 37 orang nelayan yang dijadikan sebagai responden. Angka ini diperoleh dari setengah atau $50 \%$ dari jumlah populasi yang ada di wilayah penelitian. Hal ini dimaksudkan agar mendapatkan data yang lebih akurat dan valid. Penentuan responden dilakukan secara acak (simple random sampling) dengan menggunakan kertas undian.

\section{Teknik Pengolahan dan Analisis Data}

Unit analisis penelitian ini adalah individu. Data yang telah diperoleh akan dianalisis dengan menggunakan analisis deskriptif. Analisis ini dilakukan untuk memperoleh gambaran awal mengenai keadaan atau karakteristik responden untuk masing-masing variabel. Penentuan nilai minimal pada tiap tingkatan dikerjakan dengan menggunakan prangkat lunak Minitab. Berdasarkan hasil perhitungan tersebut diperoleh quartil satu hingga tiga yang kemudian dijadikan batas tiap tingkatan. Analisis selanjutnya menggunakan perangkat lunak Microsoft Excel 2007. Kemudian membuat tabel frekuensi untuk melihat keterkaitan aspek yang menyebabkan konflik di wilayah pesisir. Kemudian digunakan tabel silang untuk melihat hubungan antara dua variabel. Untuk menguji data kuantitatif peneliti menggunakan Chi-Square dengan menggunakan perangkat lunak SPSS17 agar dapat diketahui hubungan kedua variabel.

Data kualitatif yang diperoleh akan dianalisis dengan menggunakan teknik triangulasi. Teknik ini dilakukan untuk mengurangi kesalahan intepretasi informan yang diwawancarai. Teknik ini merupakan penggabungan dari sumber-sumber yang diperoleh, yaitu data hasil wawancara, pengamatan langsung atau observasi, dan studi literatur. Gabungan data yang telah diolah dan dianalisi tersebut disajikan dalam bentuk teks naratif, tabel, matriks, atau bagan. Kemudian ditarik menjadi suatu kesimpulan.

\section{GAMBARAN UMUM}

\section{Gambaran Umum Lokasi Penelitian}

\section{Kondisi Geografi}

Kelurahan Cilacap adalah salah satu kelurahan yang ada di dalam struktur wilayah Kecamatan Cilacap Selatan, Kabupaten Cilacap, Provinsi Jawa Tengah. Kelurahan ini berbatasan dengan Kelurahan Tegalkamulyan di sebelah utara, Samudera Indonesia di sebelah selatan dan timur, serta Sungai Yasa di sebelah barat. Luas wilayah Kelurahan Cilacap adalah 171,364 ha dengan jumlah Rukun Warga sebanyak 18 RW dan Rukun Tetangga sebanyak 93 RT. Sebagian besar wlayah ini merupakan tanah kering yang berfungsi sebagai pekarangan bangunan seluas 123,567 ha. Sisanya adalah tanah hutan yang digunakan sebagai tempat wisata seluas 15 ha, tanah keperluan fasum sebagai lapangan olahraga seluas 0,5 ha 
dan kuburan seluas 0,2 ha. Selain itu terdapat pula tanah pasir seluas 20 ha.

Kelurahan Cilacap merupakan wilayah yang berbatasan langsung dengan samudera sehingga kelurahan ini memiliki sebuah pantai sebagai tempat rekreasi dan serta obyek bersejarah berupa benteng peninggalan Portugis. Lokasi ini pula yang menjadikan kelurahan ini memiliki 25 toko cindera mata yang menjual berbagai barang kerajinan hasil laut.

\section{Kondisi Sosial}

\section{Kependudukan}

Kelurahan Cilacap memiliki kepadatan penduduk sebanyak 900 orang per $\mathrm{km}^{2}$ dengan jumlah rumah tangga sebanyak 4.609 KK. Penduduk laki-laki sebanyak 9.230 jiwa dan perempuan sebanyak 8.924 jiwa. Seluruh penduduk di kelurahan tersebut merupakan Warga Negara Indonesia (WNI). Berdasarkan kepercayaan, sebagian besar penduduk menganut agama Islam, yaitu sebanyak 16.509 orang, sedangkan yang beragama Khatolik sebanyak 821 orang, Protestan sebanyak 750 orang, Hindu sebanyak sebelas orang, dan Budha sebanyak 63 orang. Selain itu, terdapat pula penduduk yang tergabung dalam Aliran Kepercayaan Terhadap Tuhan Yang Maha Esa sebanyak 25 orang. Di bawah ini diperlihatkan data kependudukan Kelurahan Cilacap berdasarkan golongan umur dengan frekuensi 5 tahun hingga akhir tahun 2010.

Tabel 1. Jumlah Penduduk Menurut Glongan Umur Kelurahan Cilacap Tahun 2010

\begin{tabular}{lcc}
\hline \multicolumn{1}{c}{ Umur } & Jumlah (jiwa) & Persentase $(\%)$ \\
\hline $0-4$ & 1313 & 7,23 \\
$5-9$ & 1515 & 8,35 \\
$10-14$ & 1525 & 8,40 \\
$15-19$ & 1856 & 10,22 \\
$20-24$ & 1422 & 7,83 \\
$25-29$ & 2274 & 12,53 \\
$30-34$ & 1462 & 8,05 \\
$35-39$ & 1501 & 8,27 \\
$>=40$ & 5286 & 29,12 \\
Total & 18154 & 100 \\
Sumber: Data Monografi Kelurahan Cilacap 2010
\end{tabular}

Berdasarkan data pada Table 1 menunjukkan bahwa persentase tertinggi adalah $29,12 \%$ yang terdapat di kisaran umur 40 tahun ke atas. Selain itu persentase penggabungan dari usia 15 tahun hingga 40 tahun ke atas menunjukkan angka $76,62 \%$ yang berarti sebanyak 13.801 jiwa merupakan penduduk berusia produktif. Sedangkan penduduk yang tergolong usia belum produktif sebanyak 4.353 jiwa.

Hal ini memperlihatkan kemungkinan mayoritas penduduk sudah dapat mencari nafkah untuk memenuhi kebutuhan hidupnya sendiri sehingga dapat berpengaruh terhadap beban tanggungan kepala keluarga. Selain itu pada Tabel 2 diperlihatkan klasifikasi penduduk berdasarkan tingkat pendidikan yang dimilikinya.

Tabel 2. Tingkat Pendidikan Penduduk Kelurahan Cilacap Tahun 2010

\begin{tabular}{lcc}
\hline \multicolumn{1}{c}{ Tingkat Pendidikan } & $\begin{array}{c}\text { Jumlah } \\
\text { (Orang) }\end{array}$ & $\begin{array}{c}\text { Persentase } \\
(\%)\end{array}$ \\
\hline Belum sekolah & 2202 & 12,18 \\
Tidak tamat sekolah & 2220 & 12,28 \\
Tamat SD/sederajat & 5713 & 31,59 \\
Tamat SLTP/sederajat & 3519 & 19,46 \\
Tamat SLTA/sederajat & 3992 & 22,08 \\
Tamat akademi/sederajat & 226 & 1,25 \\
Tamat perguruan & 210 & 1,16 \\
tinggi/sederajat & & 100,00 \\
\hline
\end{tabular}

Sumber: Data Monografi Kelurahan Cilacap 2010

Berdasarkan data di atas dapat diketahui bahwa tingkat pendidikan di Kelurahan Cilacap tergolong rendah. Hal ini dikarenakan sebanyak $12,28 \%$ penduduk tidak tamat sekolah dan $31,59 \%$ penduduk hanya tamat Sekolah Dasar. Rendahnya tingkat pendidikan masyarakat dapat berpengaruh pada akses politik berupa partisipasi mereka terkait dengan sumber daya alam.

Tabel 3. Mata Pencaharian Penduduk Kelurahan Cilacap Tahun 2010

\begin{tabular}{lcc}
\hline \multicolumn{1}{c}{ Mata Pencaharian } & Jumlah (orang) & Presentase (\%) \\
\hline Nelayan & 4063 & 59,06 \\
Industri/usaha sedang/besar & 9 & 0,13 \\
Pengrajin industri kecil & 11 & 0,16 \\
Buruh bangunan & 1721 & 25,02 \\
Pedagang & 591 & 8,59 \\
Pengangkutan & 52 & 0,76 \\
PNS & 107 & 1,56 \\
ABRI & 47 & 0,68 \\
Pensiun PNS/ABRI & 163 & 2,37 \\
Lain-lain (jasa) & 115 & 1,67 \\
\multicolumn{1}{c}{ Total } & 6879 & 100 \\
\hline
\end{tabular}

Sumber: Data Monografi Kelurahan Cilacap 2010

Jika dilihat dari Tabel 3 di atas, dapat diketahui bahwa sebagian besar penduduK memiliki mata pencaharian sebagai nelayan, yaitu 59,06\% dari jumlah keseluruhan. Sedangkan mata pencaharian terbanyak kedua yang dimiliki oleh penduduk di wilayah tersebut adalah buruh bangunan sebesar 25,02\%. Sebanyak 591orang atau $8,59 \%$ penduduk berprofesi sebagai pedagang. Hal ini menunjukkan bahwa sumber daya pesisir sangat penting bagi penduduk di Kelurahan Cilacap. 


\section{Kegiatan Perikanan}

Seperti yang telah dijelaskan sebelumnya bahwa sebagian besar penduduk Kelurahan Cilacap memiliki mata pencaharian sebagai nelayan. Jumlah nelayan yang ada di kelurahan tersebut sebanyak 4.063 orang. Sedangkan nelayan yang terdaftar sebagai anggota KUD hanya sebanyak 3.533 orang. Menurut salah seorang pegawai KUD Mino Saroyo Cilacap, hal ini disebabkan karena sebagian nelayan kurang memahami peraturan KUD mengenai pemotongan dana hasil tangkap untuk simpanan pokok, simpanan wajib, cadangan, dan donasi. Mereka berpikir bahwa dengan menjual hasil tangkap ke tengkulak lebih baik karena tidak terkena banyak potongan dana.

Berdasarkan data monografi Kelurahan Cilacap, dapat diketahui bahwa tidak semua nelayan memiliki perahu atau kapal sendiri. Pada tabel berikut ini akan diperlihatkan kepemilikan perahu dan kapal yang dimiliki oleh nelayan yang ada di Kelurahan Cilacap.

Tabel 4. Jumlah Kapal, Perahu Motor, dan Perahu Nelayan di Kelurahan Cilacap

\begin{tabular}{lcc}
\hline \multicolumn{1}{c}{ Jenis Kapal } & Jumlah (buah) & Persentase (\%) \\
\hline Kapal & 55 & 3,79 \\
Perahu Motor Tempel & 1336 & 91,95 \\
Perahu & 62 & 4,27 \\
$\quad$ Total & 1453 & 100 \\
\hline
\end{tabular}

Sumber: Data Monografi Kelurahan Cilacap 2010

Berdasarkan data pada Tabel 4 tersebut maka dapat diketahui bahwa tidak semua nelayan memiliki perahu atau kapal. Selain itu mayoritas nelayan di Kelurahan Cilacap tergolong nelayan tradisional dengan jumlah 1.398 orang. Berdasarkan hasil wawancara dengan Pak S, salah satu pegawai Dinas Kelautan dan Perikanan Kabupaten Cilacap, nelayan tradisional secara peraturan hanya boleh melaut di jalur satu, yaitu sejauh enam mil. Namun tidak jarang para nelayan ini melanggar batas wilayah tangkap mereka. Nelayan tradisional adalah nelayan yang memiliki perahu sebesar 10 GT ke bawah.

Nelayan tradisional tersebut dibagi ke dalam empat jenis, yaitu nelayan perahu dayung yang memiliki perahu sebesar 2 GT, nelayan perahu viber glass dengan perahu sebesar 5 GT, nelayan perahu compreng dengan perahu sebesar 7 GT, dan nelayan perahu rumah dengan perahu sebesar 10 GT. Sedangkan kapal merupakan jenis kapal yang dimiliki oleh nelayan modern yang memiliki ukuran lebih dari 10 GT. Jenis kapal seperti ini biasanya melaut selama berminggu-minggu hingga berbulan-bulan dengan luas wilayah tangkap hingga ke ZEE.

\section{Sejarah Pelabuhan}

Cilacap adalah salah satu wilayah di Indonesia yang memiliki pelabuhan besar di Indonesia. Pelabuhan di wilayah tersebut bernama Pelabuhan Tanjung Intan yang merupakan pelabuhan kelas I. Pelabuhan ini dibangun oleh Pemerintah Hindia Belanda pada hari Senin Legi tanggal 29 November 1847 oleh Gubernur Jenderal JJ. Rochussen, sesuai Besluit No. 1 tanggal 29 November 1847 dan ditetapkan dalam staatblad No. 147 tahun 1917 sebagai pelabuhan alam dengan posisi geografis 07044'55" LS dan 109059'30" BT. Pelabuhan ini terlindungi oleh Pulau Nusakambangan dan satu-satunya pelabuhan terbesar di pantai selatan Pulau Jawa yang merupakan pintu gerbang perekonomian bagi daerah Jawa Tengah bagian selatan dengan Hinterlend di wilayah Banjarnegara, Purbalingga, Banyumas, Cilacap, dan Kebumen (BARLINGMASCAKEB), D.I. Yogayakarta, dan Jawa Barat bagian timur untuk perdagangan eksporimpor maupun antar pulau. Pelabuhan Intan telah memperoleh akreditasi internasional berupa sertifikat ISO-9002 Bidang Pelayanan Kapal dari PT Kema Registered Quality Nederland tanggal 17 September 1998. Kemudian pada tahun 2003 ditatar menjadi ISO 9001-2000 bidang pelayanan kapal dan barang terintegrasi dengan SMK3L dan telah mendapatkan sertifikat ISPS Code.

Berikut ini adalah gambar kapal-kapal yang berlabuh di Pelabuhan Tanjung Intan.

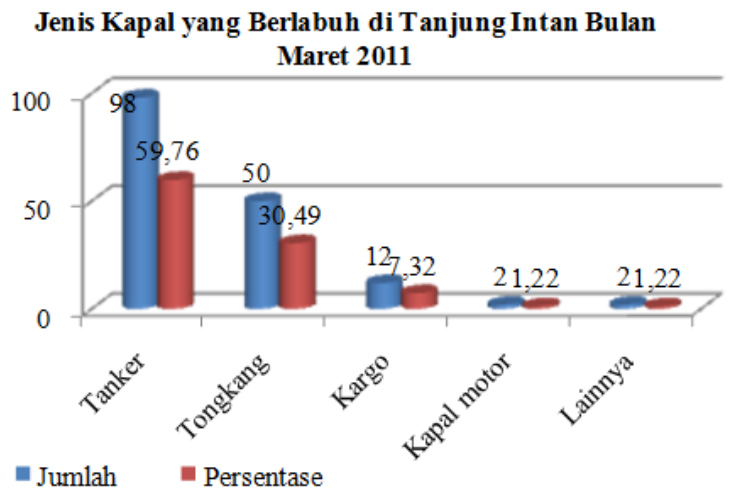

Sumber: Departemen Administrasi Pelabuhan, 2011

Gambar 2. Jenis Kapal yang Berlabuh di Tanjung Intan

Bedasarkan Gambar 2 di atas dapat diketahui bahwa jumlah kapal yang berlabuh di Pelabuhan Tanjung Intan sebanyak 164 buah pada bulan Maret 2011. Rata-rata jumlah kapal yang merapat di pelabuhan itu sekitar angka tersebut setiap bulannya. Jenis-jenis kapal yang berlabuh di sana didominasi oleh kapal tanker yang mengangkut minyak bumi, yaitu sebanyak 98 buah atau 59,76\%. Sedangkan posisi kedua terbanyak adalah kapal tongkang dengan jumlah 50 buah atau 30,49\%.

Dengan jumlah sedemikian banyak maka tidak jarang bagi kapal-kapal tersebut untuk menunggu lama agar dapat dipandu oleh kapal pemandu untuk merapat ke dermaga. Bagi kapal dengan ukuran yang sangat besar maka tidak dapat memasuk pelabuhan. Khusus bagi kapal-kapal tersebut disediakan dermaga yang memiliki fasilitas pipa dalam laut sehingga kapal dapat menyalurkan komoditi yang dibawanya walaupun ada di tengah samudera. Dermaga tersebut ada di Pulau Nusakambang- 
an yang disebut dengan dermaga Single Point Mooring (SPM).

\section{Karakteristik Responden}

Responden dalam penelitian ini memiliki homogenitas dalam mata pencaharian, yaitu nelayan. Sedangkan untuk umur, responden terdiri dari berbagai macam kelompok umur. Berikut ini adalah gambaran sebaran umur para responden.

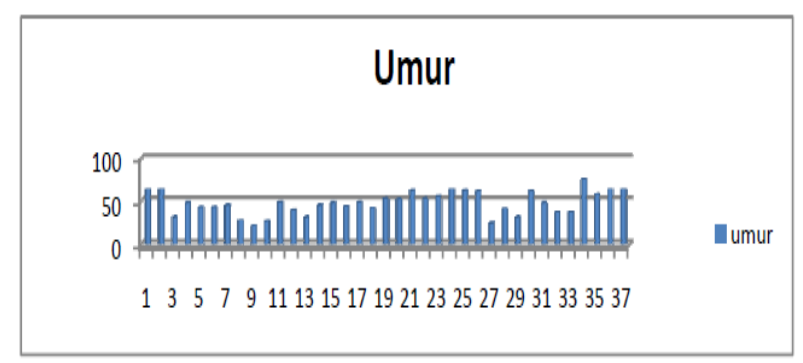

Gambar 6 Tingkat Umur Responden Kelurahan Cilacap

Berdasarkan gambar tersebut dapat dilihat bahwa umur tertua responden adalah 75 tahun. Sedangkan mayoritas responden memiliki umur di atas 40 tahun, namun ada pula beberapa responden yang masih berumur di bawah 30 tahun. Berikut ini adalah tabel mengenai tingkat pendidikan responden.

Tabel 5. Tingkat Pendidikan Responden Kelurahan Cilacap Tahun 2010

\begin{tabular}{lcc}
\hline \multicolumn{1}{c}{ Tingkat pendidikan } & Jumlah & Persentase $(\%)$ \\
\hline Tidak Sekolah atau Tamat & 25 & 67,57 \\
SD & & \\
Tamat SMP & 11 & 29,37 \\
Tamat SMA atau PT & 1 & 2,70 \\
$\quad$ Jumlah & 37 & 100 \\
\hline
\end{tabular}

Berdasarkan Tabel 5 dapat diketahui bahwa tingkat pendidikan responden tergolong rendah. Sebagain besar responden hanya mengenyam bangku sekolah hingga SD atau bahkan tidak tamat SD. Sedangkan yang mengenyam bangku sekolah hingga SMA hanya satu orang saja. Responden yang memiliki tingkat pendidikan hanya sampai SD atau bahkan tidak sekolah itu kebanyakan adalah responden dengan usia di atas 40 tahun. Mereka mengatakan bahwa hal ini terjadi karena pada saat usia itu mereka sudah melaut bersama orang tua. Jadi dapat dikatakan bahwa pada saat anak seusianya belajar di SD, sebagian dari mereka sudah membantu mencari nafkah sehingga tidak dapat sekolah.

Namun ternyata tingkat pendidikan para responden tidak berpengaruh terhadap tingkat pendapatan mereka. Berdasarkan hasil kuesioner yang diperoleh hal tersebut terbukti. Pada Gambar 7 dapat dilihat bahwa mayoritas responden memiliki tingkat pendapatan tinggi di mana tabung mencapai angka tiga. Hal ini berarti sebanyak 18 responden memiliki pendapatan di atas Rp152.500,00 dalam sekali melaut, sedangkan delapan responden yang berada pada tingkat sedang atau tabung mencapai angka dua memiliki pendapatan di atas Rp54.375,00 hingga Rp152.500,00 dalam sekali melaut. Rsponden yang memiliki tingkat pendapatan rendah sebanyak sepuluh orang dengan penghasilan maksimal Rp54.375,00 setiap kali melaut. Berikut ini adalah gambar tingkat pendapatan mereka.

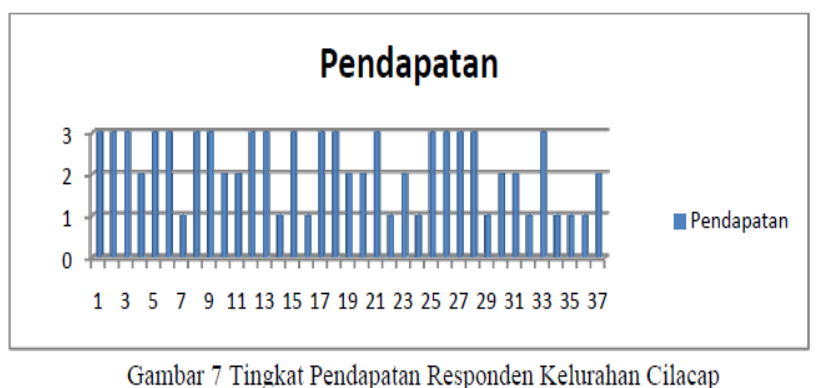

Pendapatan per hari yang mereka terima sebagian digunakan untuk kepentingan melaut pada keesokkannya dan sebagian lagi digunakan untuk menghidupi keluarga yang mereka miliki. Para responden memiliki beban tanggungan yang berbeda-beda. Berikut ini adalah gambar tingkat beban tanggungan para responden.

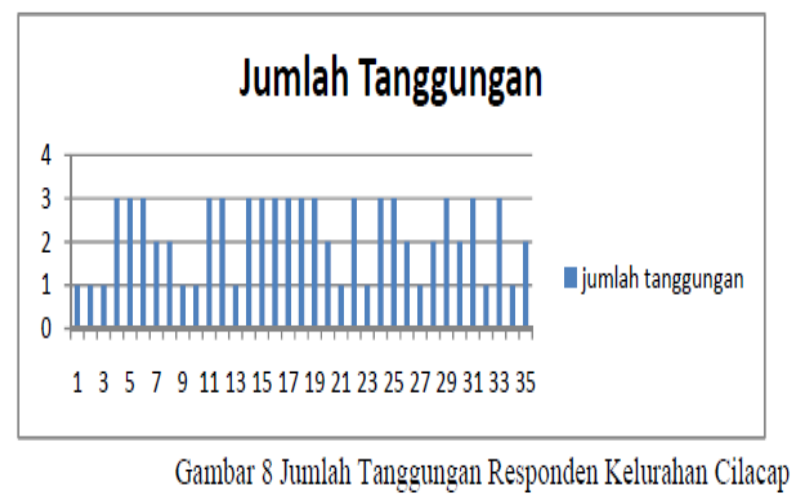

Berdasarkan Gambar 8 dapat dilihat bahwa sebanyak 17 orang memiliki jumlah tanggungan minimal tiga orang. Berdasarkan data tersebut, responden yang memiliki jumlah tanggungan minimal tiga orang tergolong responden yang memiliki tingkat beban tanggungan tinggi. Responden dengan tingkat beban tanggungan sedang sebanyak tujuh orang, yaitu hanya memiliki dua tanggungan. Selain itu terdapat 13 orang responden yang memiliki beban tanggungan rendah dalam arti hanya memiliki satu beban tanggungan atau hanya hidup seorang diri.

\section{HASIL PENELITIAN}

\section{Hubungan Karakteristik Nelayan dengan Tingkat Partisipasi Nelayan}

Berdasarkan penelitian yang telah dilakukan dapat disimpulkan bahwa tidak terbentuk hubungan antara karakteristik nelayan dengan tingkat partisipasi nelayan. Berdasarkan data yang diperoleh, dalam pembangunan 
dermaga dan jalur pelayaran kapal nonnelayan dapat diketahui bahwa pembangunan tersebut merupakan pembangunan yang top down. Walaupun benar adanya bahwa terdapat sosialisasi mengenai keberadaan kedua hal tersebut kepada pihak nelayan.

Selain itu ada pula rapat yang diselenggarakan oleh pihakpihak terkait, seperti pemerintah lokal dengan persatuan nelayan untuk mem-bahas soal tersebut. Namun, berdasarkan hasil kuesioner yang diperoleh, nelayan lebih banyak berpartisipasi dalam tahap evaluasi. Berikut ini adalah gambaran mengenai tahapan tersebut.

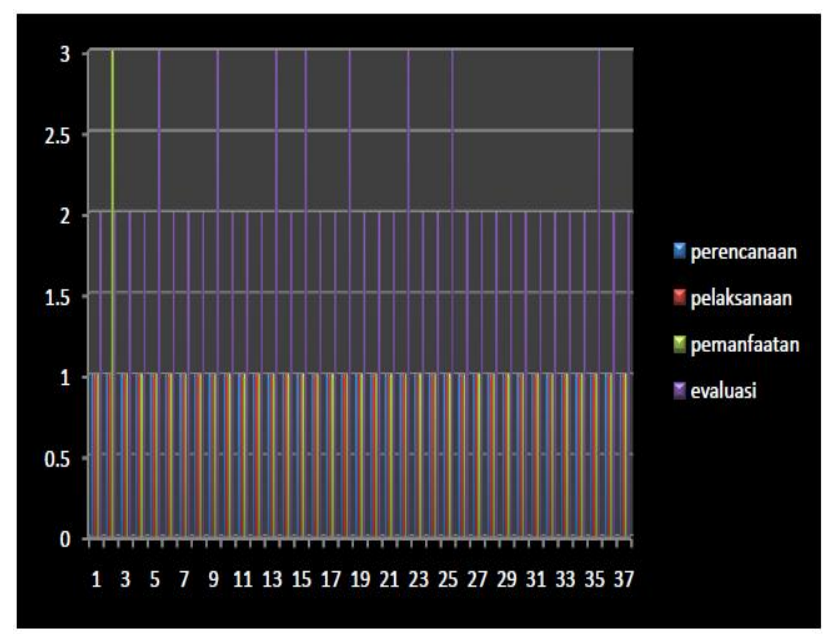

Gambar 9 Tingkat Partisipasi Nelayan Dalam Tiap Tahapan

Berdasarkan Gambar 9 di atas dapat diketahui bahwa $100 \%$ responden memiliki tingkat partisipasi yang rendah dalam tahap perencanaan dan pelaksanaan. Sedangkan pada tahap pemanfaatan, terdapat $2,5 \%$ responden yang memiliki peran serta yang tinggi. Pada tahap akhir, yaitu tahap evaluasi, nelayan memiliki peran serta yang tergolong tinggi dan sedang. Sebanyak $78,38 \%$ nelayan memiliki tingkat partisipasi sedang. Sementara $21,62 \%$ lainnya memiliki tingkat partisipasi tinggi. Namun walaupun begitu, karena sebagian besar dari mereka hanya aktif pada tahap evalusai saja maka hal ini tidak terlalu berpengaruh pada keseluruhan peran aktif tingkat partisipasi mereka.

Berdasarkan hasil uji dengan menggunakan Chi-Square, derajad kebebasan yang digunakan adalah 2 dengan alfa 0,1 serta nilai tabel yang dihasilkan adalah 4,61. Berdasarkan nilai hitung yang diperoleh dari setiap hubungan masing-masing variabel karakteristik sosial dengan tahap evaluasi diketahui bahwa variabel pendidikan mempengaruhi tingkat partisipasi responden. Semakin tinggi pendidikan seseorang maka dia akan memiliki tingkat partisipasi yang lebih tinggi pula. Sedangkan pada variabel lainnya hubungan yang terjadi tidak signifikan.
Tabel 6. Hubungan Karakteristik Sosial dengan Tahap Evaluasi

\begin{tabular}{|c|c|c|c|c|}
\hline \multirow{2}{*}{$\begin{array}{c}\text { Karakteristik } \\
\text { Sosial }\end{array}$} & & \multicolumn{3}{|c|}{ Evaluasi } \\
\hline & & Tinggi & Sedang & Rendah \\
\hline \multirow{3}{*}{ Umur } & Tinggi & 3 & 14 & 0 \\
\hline & Sedang & 3 & 7 & 0 \\
\hline & Rendah & 2 & 8 & 0 \\
\hline \multirow{4}{*}{ Pendidikan } & Tinggi & 1 & 0 & 0 \\
\hline & Sedang & 4 & 7 & 0 \\
\hline & Rendah & 3 & 22 & 0 \\
\hline & Tinggi & 6 & 12 & 0 \\
\hline \multirow{3}{*}{$\begin{array}{c}\text { Pendapatan } \\
\text { Tidak } \\
\text { Paceklik }\end{array}$} & Sedang & 0 & 9 & 0 \\
\hline & Rendah & 2 & 8 & 0 \\
\hline & Tinggi & 2 & 4 & 0 \\
\hline \multirow{3}{*}{$\begin{array}{c}\text { Pendapatan } \\
\text { Saat } \\
\text { Paceklik }\end{array}$} & Sedang & 3 & 8 & 0 \\
\hline & Rendah & 3 & 17 & 0 \\
\hline & Tinggi & 5 & 12 & 0 \\
\hline \multirow{2}{*}{$\begin{array}{c}\text { Jumlah } \\
\text { Tanggungan }\end{array}$} & Sedang & 1 & 6 & 0 \\
\hline & Rendah & 2 & 11 & 0 \\
\hline
\end{tabular}

\section{Keterkaitan Partisipasi Nelayan dalam Menentukan Wilayah Zonasi Pesisir}

Bab sebelumnya telah dijelaskan baik secara kuantitatif maupun secara kualitatif bahwa pada kenyataannya karakteristik individu nelayan tidak mempengaruhi tingkat partisipasi nelayan. Selain itu, tingat partisipasi nelayan yang tergolong rendah secara keseluruhan juga tidak berpengaruh terhadap pembentukkan zonasi yang terdapat di perairan Cilacap. Penyebabnya adalah pembentukkan zonasi yang terdapat di sana merupakan hasil keputusan langsung dari pemerintah pusat (top down). Namun jika dilihat, perairan tersebut memiliki dua zonasi utama, yaitu zonasi pertambangan dan zonasi perikanan. Pada bab ini akan lebih difokuskan pada zonasi dua kegiatan tersebut dan pemanfaatannya.

Batas perairan yang ada di Kabupaten Cilacap khususnya darah Pelabuhan Tanjung Intan hingga saat ini masih berpegang pada Surat Keputusan Bersama 2 Menteri yaitu Menteri Perhubungan dan Menteri Dalam Negeri No. 13/1986 KM 31/AL-101/PHB-86. Pada tahun 1986 saat disahkan peraturan tersebut rezim kepemilikan sumber daya alam yang terbentuk adalah rezim negara. Rezim ini berimplikasi kepada kepemilikan dan pengatuaran sumber daya yang ada di mana pemerintah merupakan pihak yang 
berhak menentukan pengelolaannya. Pada waktu itu pemerintah menetapkan bahwa wilayah perairan Cilacap menjadi wilayah pelayaran. Namun dengan seiring berjalannya waktu pada tahun 2004 telah disahkan UndangUndang Nomor 32 mengenai pemerintah daerah dan tahun 2007 disahkan Undang-Undang Nomor 27 tentang Pengelolaan Wilayah Pesisir dan Pulau-Pulau Kecil. Dalam kedua undang-undang tersebut dijelaskan bahwa pemerintah provinsi memiliki wewenang atas laut paling jauh dua belas mil dari garis pantai ke laut lepas. Sementara kabupaten atau kota memiliki wewenang empat mil atau 1/3 dari wilayah kewenangan provinsi.

Pengelolaan pesisir yang terdapat di Cilacap hingga saat ini masih tergolong rezim negara karena tidak ada pengalihan atau pemindahtanganan pengelolaan sumber daya alam kepada masyarakat atau swasta. Namun dengan melihat zonasi yang terdapat di perairan tersebut dapat dilihat bahwa pada jarak empat mil menuju laut lepas dari garis pantai terdapat alur pelayaran. Keadaan ini menyebabkan nelayan tidak dapat mengakses wilayah tersebut untuk menangkap ikan secara bebas. Maka dapat dikatakan bahwa terdapat konflik rezim negara di dalam pengelolaan sumber daya pesisir di Cilacap ini.

Undang-Undang Nomor 27 Tahun 2007 yang telah disahkan tersebut belum diimplementasikan di wilayah perairan Cilacap. Hal yang sama pun terjadi pada Undang- Undang Nomor 32 Tahun 2004. Kegiatan yang dapat dilakukan hingga saat ini adalah kegiatan yang berasaskan saling pengertian antara dua kegiatan yang berada pada wilayah yang sama. Kegiatan nelayan tangkap tidak boleh mengganggu alur pelayaran kapal. Nelayan dianjurkan untuk melaut di wilayah tangkap lain walaupun mereka punya hak atas wilayah tersebut.

Kondisi yang mirip juga terjadi di Tanjung Priok Jakarta. Merujuk pada hasil tesis Effendy Batubara (2005) tentang Penetapan dan Pengelolaan Alur Pelayaran dan Perairan Pelabuhan Studi Kasus Teluk Jakarta, dikatakan bahwa terdapat konflik pemanfaatan ruang perairan antara perikanan tangkap dengan alur pelayaran. Konflik ini terjadi karena wilayah tangkap nelayan tradisional berada dalam berada dalam Daerah Lingkungan Kerja (DLKR) dan Daerah Lingkungan Kepentingan (DLKP) perairan pelabuhan. Hal ini juga terjadi di perairan Cilacap di mana wilayah tangkap nelayan tradisional juga berada dalam alur pelayaran pelabuhan. Hal ini dapat dilihat pada Gambar 10 halaman 52 di mana wilayah untuk melego jangkar kapal hanya berjarak dua hingga tiga mil dari garis pantai. Kondisi ini berarti di area itu pula terdapat wilayah tangkap nelayan tradisional dengan jarak tempuh 0-6 mil dari garis pantai. Namun pada kasus di perairan Cilacap ini sebagian besar nelayan memang mengalah dan tidak melakukan penangkapan ikan di area lego jangkar dan sekitarnya. Walaupun menurut nelayan di wilayah tersebut terdapat banyak hasil tangkapan. Nelayan lebih memilih jalan aman daripada jaring yang mereka tebar terkena jangkar. Pada umumnya panjang tali jangkar yang dibutuhkan saat labuh secara empirik adalah tiga seckle rantai atau tiga kali $27,5 \mathrm{~m}$. Namun, untuk mengingkatkan keamanan di perairan dibutuhkan panjang rantai enam kali kedalaman perairan. Semakin pendek tali jangkar yang digunakan makin kecil areal labuh yang dibutuhkan. Namun sayangnya nelayan tetap tidak mengetahui di mana tepatnya letak jangkar kapal tersebut sehingga kemungkinan jaring nelayan tersangkut jangkar tetap ada.

Menurut Batubara (2005), interaksi konflik keruangan antara alur pelayaran dengan perikanan tangkap nelayan tradisional tersebut menghalangi olah gerak kapal dan alat tangkap seperti jaring dan long line dapat membahayakan keselamatan kapal. Di lain pihak kegiatan pelayaran tersebut membahayakan alat tangkap atau kapal ikan. Hal ini juga diperkuat dengan beberapa kejadian di perairan Cilacap di mana beberapa kali terjadi kecelakaan kapal nelayan tradisional karena jaringnya tertabrak kapal tanker.

Selain itu menurut Batubara (2005), kegiatan kapal juga memberikan dampak negatif terhadap kegiatan perikanan, yaitu berupa terjadinya pencemaran perairan oleh kegiatan kapal berupa limbah cair berminyak. Limbah ini menyebabkan menjauhnya ikan dari area penangkapan ikan. Berdasarkan uraian tersebut, Batubara menyimpulkan bahwa interaksiyang terjadi antara dua kegiatan pemanfaatan ruang yang sama ini merugikan kedua kegiatan. Keadaan ini juga terjadi di perairan Cilacap. Ketika jaring nelayan tersangkut di jangkar hingga rusak maka nelayan tidak dapat melaut dan pihak kapal mengganti rugi kecelakaan tersebut. Namun berdasarkan hasil wawancara dengan KPLP diketahui bahwa untuk mendapatkan ganti rugi dari pihak kapal, nelayan harus memiliki bukti otentik sehingga dapat dibandingkan dengan bukti yang ada di kapal tersebut.

\section{Pengaruh Zonasi Wilayah Pesisir terhadap Akses Sumber Daya Alam Nelayan}

Zonasi wilayah pesisir dapat dikatakan mempengaruhi akses sumber daya alam nelayan. Perubahan jauhnya jarak serta lamanya waktu tangkap nelayan merupakan salah satu indikasi bahwa zonasi ini mempengaruhi akses nelayan. Selain itu dengan adanya kapal nonnelayan yang semakin banyak hilir mudik menuju pelabuhan dan harus melakukan lego jangkar terlebih dahulu maka membuat ada sebagain wilayah lautan yang tidak dapat dijamah oleh para nelayan. Selain itu hal ini juga membuat nelayan harus lebih waspada dalam menyebar jaringnya agar tidak terkena jangkar pada kapal yang sedang menunggu giliran untuk masuk dermaga. Sedangkan untuk perubahan jumlah tangkapan yang sangat signifikan tersebut, masih dibutuhkan penelitian lanjutan agar mengetahui dengan pasti penyebab dari terjadinya hal tersebut. Mungkin hal ini hanya disebabkan oleh cuaca dan iklim atau laut yang tercemar sebagai efek tidak langsung dari jumlah kapal non nelayan yang semakin meningkat karena adanya zonasi. Namun, hal ini juga bisa disebabkan karena perpaduan keduanya atau alasan lain. 


\section{Pengaruh Akses Sumber Daya Alam terhadap Konflik}

Perubahan akses sumber daya alam yang dialami oleh nelayan tidak terlalu berpengaruh terhadap konflk yang terjadi. Hal ini disebabkan para nelayan lebih banyak pasrah atas keadaan yang terjadi. Hal ini terlihat pada nelayan yang tetap melaut pada jarak dan dalam waktu yang sama. Nelayan tidak dapat berbuat banyak untuk meningkatkan hasil tangkapannya. Selain itu mereka pun tidak mengetahui faktor penyebab yang mengakibatkan musim paceklik terjadi selama tiga tahun terakhir ini.

Konflik yang terjadi selama ini disebabkan oleh keberadaan kapal tanker dan tongkang saat mengalami kecelakaan. Kecelakaan ini menyebabkan konflik lingkungan di wilayah tersebut. Semenjak tahun 1975, yaitu saat salah satu industri mulai dibangun di Cilacap sudah ada tiga kecelakaan kapal tanker. Dua di antaranya yaitu kapal tanker MT. King Fisher dan Lucky Lady. Pada Gambar 10 diperlihatkan bagaimana proses terjadinya konflik lingkungan tersebut.

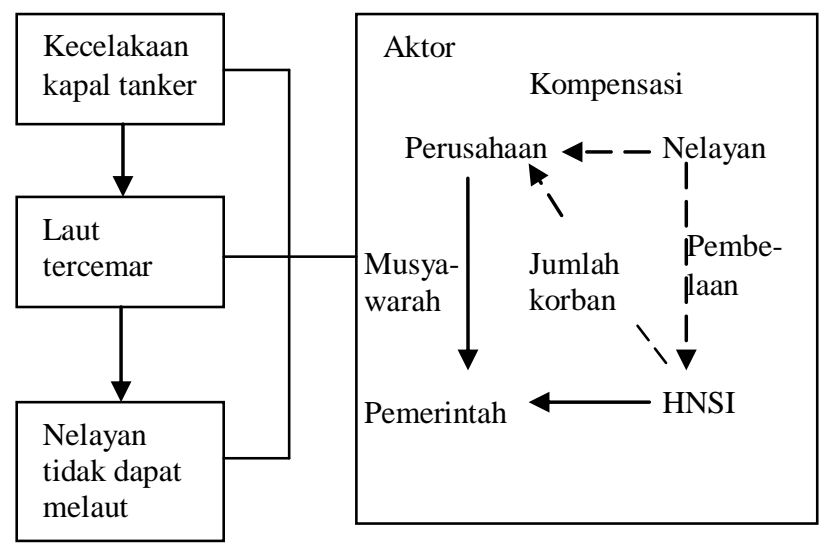

Keterangan 1:

$=$ berhubungan

$=$ menyebabkan

Keterangan 2:

$\longrightarrow \quad=$ konflik

$\longrightarrow \quad=$ meminta

Gambar 10. Proses Konflik Lingkungan

Konflik lingkungan yang terjadi antara nelayan dan perusahaan pertambangan memiliki dua sifat, yaitu terbuka dan laten. Konflik terbuka terlihat ketika nelayan mulai melakukan demonstrasi atas penolakan perusahaan pertambangan dan pemberhentian pembersihan minyak mentah yang tumpah. Akar masalah ini adalah nelayan kehilangan mata pencahariannya karena pencemaran yang terjadi.

Konflik laten antara nelayan dengan perusahaan pertambangan terjadi setelah dana kompensasi telah dibagikan. Nelayan merasa jumlah uang kompensasi yang mereka terima tidak sebanding dengan kerugian yang mereka alami. Namun mereka hanya diam saja dan pasrah menerima keadaan. Di pihak lain, mereka meragu dampak jangka panjang dari pencemaran tersebut. Mereka menduga bahwa paceklik selama tiga tahun ini dipengaruhi oleh kecelakaan yang terjadi saat itu.
Konflik laten juga terjadi antara nelayan dengan organisasi tempat mereka bernaung, yaitu kelompok nelayan dan HNSI. Hal ini terjadi karena adanya penurunan nilai kepercayaan. Jumlah kompensasi yang diberikan perusahaan pertambangan mencapai miliyaran rupiah, namun nelayan hanya mendapatkan jumlah yang kecil. Selain itu, peningkatan jumlah nelayan yang melambung tinggi saat adanya kecelakaan juga membuat kepercayaan para nelayan menjadi menurun.

Konflik yang terjadi di perairan Cilacap tersebut adalah konflik vertikal. Konflik ini berbentuk vertikal karena melibatkan dua pihak yang memiliki kedudukan berbeda, yaitu nelayan dengan perusahaan pertambangan. Perbedaan kedudukan ini mengakibatkan nelayan didominasi oleh perusahaan pertambangan.

Konflik ini diselesaikan dengan berbagai macam cara. Untuk mencapai suatu kesepakatan maka dilakukan konsiliasi di mana diadakan sebuah pertemuan yang melibatkan seluruh perwakilan pihak terkait. Pemerintah menjadi mediator yang berfungsi sebagai penasihat antara kedua belah pihak, HNSI dan perusahaan pertambangan, dalam musyawarah. Di akhir keputusan, perusahaan akan memberikan kompensasi kepada nelayan berdasarkan jumlah nelayan yang menjadi korban serta jumlah dana kompensasi yang telah disepakati dalam pertemuan tersebut.

Berdasarkan pengamatan dari penelitian ini dapat dilihat bahwa terdapat beberapa dampak negatif yang terjadi, yaitu 1) penurunan kepercayaan di kalangan nelayan terhadap perusahaan dan organisasi tempat mereka bernaung; 2) polarisasi nelayan, terdapat kelompok nelayan yang asih percaya pada HNSI dan ada yang kurang percaya lagi; dan 3) timbul masalah moral.

Selain dampak negatif, konflik yang terjadi juga menimbulkan dampak positif, yaitu 1) ikatan kelompok lebih erat; 2) penyesuaian diri pada kenyataan dilakukan oleh para nelayan yang tetap ingin melaut walaupun harus menempuh jarak yang lebih jauh; dan 3) pengetahuan atau keterampilan meningkat.

\section{Saran}

Beberapa saran yang dapat diajukan dari hasil penelitian ini adalah:

1. melakukan implementasi atas Undang-Undang Nomor 27 Tahun 2007 dan Undang-Undang Otonomi Daerah Nomor 32 Tahun 2004 dengan baik;

2. manfaatkan wilayah kewenangan pemerintah daerah dengan mengusahakan berbagai kegiatan perikanan di daerah perairan lokasi penelitian sesuai dengan keadaan alam di wilayah tersebut;

3. memulihkan daerah nursery ground yang berada di wilayah tersebut agar keberadaan ikan kembali banyak; 
4. merancang pembangunan secara terpadu dengan pihak pelabuhan dalam rangka pemanfaatan wilayah pesisir yang berkelanjutan;

5. peningkatan sosialisasi mengenai jalur pelayaran kapal tanker dan tongkang agar tidak ada lagi jaring nelayan yang rusak karena tersangkut.

\section{DAFTAR PUSTAKA}

Adhuri DS. 2005. Perang-perang atas laut, menghitung tantangan pada manajemen sumber daya laut di era otonomi: pelajaran dari Kepulauan Kei, Maluku Tenggara.

Jurnal Antropologi Indonesia. [Internet]. [Dikutip 29 Desember 2010]; 29(03): 300-308.

Aprinova C. 2006. Pemberdayaan komunitas miskin. Studi kasus di Desa Mambalan,Kecamatan Gunungsari, Kabupaten Lombok Barat, Propinsi NTB. [Tesis]. Bogor [ID]:Institut Pertanian Bogor.

Batubara E. 2005. Penetapan dan pengelolaan alur pelayaran dan perairan pelabuhan studikasus Teluk Jakarta. [Tesis]. Bogor [ID]: Institut Pertanian Bogor.

Dahuri R, Rais J, Ginting PS, Sitepu MJ. 1996. Pengelolaan sumber daya wilayah pesisir danlautan secara terpadu. Jakarta [ID]: Pradnya Paramita.

Farid M. 2005. Program pemberdayaan ekonomi masyarakat pesisir (PEMP) dan partisipasi masyarakat pemanfaatan program kasus Desa Semedusari dan Desa Tambaklekok,Kecamatan Lekok, Kabupaten Pasuruan, Provinsi Jawa Timur. [Skripsi]. Bogor [ID]:Institut Pertanian Bogor.

Harmantyo D. 2007. Pemekaran daerah dan konflik keruangan, kebijakan otonomi daerah dan implementasinya di Indonesia. Jurnal Makara, Sains. [Internet]. [Dikutip 6 November 2010]; 11(01): 16-22.

Hikmah Z. 2008. Analisis konflik nelayan dalam pengelolaan sumber daya perikanan Selat Madura dalam perspektif sosiologis-hukum. [Skripsi]. Bogor [ID]: Institut Pertanian Bogor.

Pickering P. 2001. How to manage conflict, kiat menangani konflik. edisi ketiga. Jakarta [ID]: Erlangga.

Satria A. 2009. Ekologi politik nelayan. Jakarta [ID]: LkiS Printing Cemerlang.

.2009. Pengantar sosiologi masyarakat pesisir. Jakarta [ID]: Pustaka Cidesindo.

Singarimbun M. 2006. Metode penelitian survai. Yogyakarta [ID]: Pustaka LP3ES Indonesia.

Soekanto S. 2002. Sosiologi suatu pengantar. Jakarta [ID]: Raja Grfindo Persada.
Susan N. 2010. Pengantar sosiologi konflik dan isu-isu konflik kontemporer. Jakarta [ID]: Kencana Prenada Media Group.

Uphoff NT, Cohen JM, Athur A. 1979. Rural development committe feasibility and aplication of rural develompment participation - a state-of-theart populer. Cornell University [US]. 
